\title{
ADA APA DENGAN KOMUNIKASI ORANG TUA-REMAJA?: PENGARUHNYA TERHADAP AGRESIVITAS REMAJA PADA SESAMA
}

\author{
Diana Berlianti ${ }^{\left.{ }^{*}\right)}$, Aida Vitayala²${ }^{2}$ Dwi Hastuti ${ }^{3}$, Sarwititi Sarwoprasodjo $^{2}$, Diah Krisnatuti ${ }^{3}$ \\ ${ }^{1}$ Penulis lepas, Mahasiswa Program Doktoral Program Studi Komunikasi Pertanian Pedesaan, Institut Pertanian \\ Bogor, Bogor 16880, Indonesia \\ 2 Departemen Sains Komunikasi dan Pengembangan Masyarakat, Fakultas Ekologi Manusia, Institut Pertanian \\ Bogor, Bogor 16880, Indonesia \\ ${ }^{3}$ Departemen IImu Keluarga dan Konsumen, Fakultas Ekologi Manusia, Institut Pertanian Bogor, Bogor 16880,
} Indonesia

*) E-mail: diana.berlianti@gmail.com

\begin{abstract}
Abstrak
Penelitian tentang komunikasi orang tua-remaja yang dihubungkan dengan agresivitas remaja pada sesama belum banyak dilakukan. Studi ini penting karena biasanya pelaku kekerasan adalah korban kekerasan pada masa lalu. Kajian ini menganalisis pengaruh pola komunikasi orang tua-remaja, perilaku komunikasi kekerasan fisik dan verbal orang tua pada remaja, dan komunikasi saling menarik diri orang tua-remaja terhadap frekuensi dan agresivitas remaja pada sesama. Penelitian ini menggunakan kerangka teoritis teori kognisi sosial Albert Bandura tentang reproduksi pesan kekerasan. Studi dilakukan pada 367 remaja di Kota dan Kabupaten Bogor. Kajian ini menggunakan metode kuantitatif dengan desain studi dalam jangka waktu tertentu. Pengumpulan data dilakukan dengan teknik survei dan laporan diri, dengan menggunakan analisis model persamaan struktural. Hasil menunjukan pengaruh signifikan antara tingginya perlakuan kekerasan verbal dan nonverbal orang tua pada remaja, serta komunikasi saling menarik diri orang tua-remaja terhadap frekuensi kekerasan dan perasaan agresivitas remaja. Kajian ini membuktikan bahwa korban kekerasan biasanya akan menjadi pelaku kekerasan di masa mendatang.
\end{abstract}

Kata kunci: frekuensi agresi, kekerasan orang tua pada remaja, komunikasi saling menarik diri

\section{What's with Parent-Adolescent Communication? Effects on Adolescent's Aggresiveness Toward Others}

\begin{abstract}
There is a vague link between parent-adolescent communication and adolescents' aggressiveness. Usually, the agressive perpetrators are the victims from their past experiences of abusive behavior from their surroundings. This present study aimed to examine influence among parent-adolescent communication pattern, parental physically and verbally harsh communication toward adolescents, parents-adolescents mutual avoidance, frequency of adolescents aggressivity toward others, and adolescents aggressiveness. Using Albert Bandura's learning theoretical framework about violence messages reproduction, this study have been conducted using 367 adolescents sample of Bogor District and City. This report used quantitative and using cross sectional study design. Researcher also employed self-reported, survey methods in order to collect data. Result shown significant relation and influence among parental physically and verbally communication towards adolescents; parents-adolescents mutual avoidance; frequency of adolescents aggressivity toward others; and adolescents aggressiveness. Using Structural Equation Modelling (SEM) analyses, result proved that the victims of violence usually become perpetrators in future life.
\end{abstract}

Keywords: frequency of agressivity, parents-adolescents mutual avoidance, parental communication behavior towards adolescents

\section{PENDAHULUAN}

Kekerasan adalah salah satu dari perilaku yang paling sering terjadi dan paling merusak yang dihadapi oleh remaja saat ini, baik sebagai korban maupun pelaku (Rina, 2011). Data yang dihimpun oleh Komisi Perlindungan Anak Indonesia (KPAl) menunjukkan adanya peningkatan kasus kekerasan yang dilakukan oleh remaja berupa tawuran antar pelajar dari tahun ke tahun (Setyawan, 2014). Berbeda dengan konsep awam, kekerasan (violence) dalam psikologi sosial merupakan bagian ekstrim dari agresi yang ditujukan untuk melukai orang lain (Anderson \& Bushman, 2002; Allen \& Anderson, 2015), sedangkan 
agresi atau agresivitas adalah sebuah perilaku atau kapasitas kekejaman, keyakinan, pemikiran, keinginan, dan kemarahan yang ditujukan pada orang lain dengan niat sengaja untuk menyakiti atau mencelakakan orang tersebut (Allen \& Anderson, 2015). Agresi dan kekerasan berada pada sebuah kontinum, dengan kekerasan pada ujung ekstrimnya. Setiap kekerasan pasti melibatkan agresivitas, tetapi tidak semua agresi adalah kekerasan (Allen \& Anderson, 2015).

Studi sebelumnya tentang agresivitas remaja seringkali terfokus pada bentuk agresi fisik (Verona \& Kilmer, 2007). Meskipun demikian, kekerasan fisik hanyalah salah satu bagian dari kekerasan saja. Kekerasan dalam banyak jenisnya (fisik, verbal, psikologikal, emotional, overt, covert) selalu menjadi perdebatan hangat para ilmuwan (Verona et al., 2008). Selain frekuensi, agresivitas remaja juga dapat diukur dari perasaan agresif yaitu agresivitas fisik, verbal, kemarahan dan kekejaman remaja pada sesama (Buss \& Perry, 1992; Lochman \& Dodge, 1998). Penelitian ini melihat kekerasan remaja tidak saja pada frekuensi agresi, tetapi juga pada agresi fisik, verbal, kemarahan, dan kekejaman remaja pada sesama.

Agresivitas remaja pada sesama, salah satunya dibentuk oleh pola yang berlangsung terus menerus secara repetitif di dalam lingkungan interaktifnya termasuk keluarga (Klein \& White, 2002). Untuk dapat melakukan tindakan kekerasan pada sekitarnya, manusia harus memiliki kapasitas untuk bersikap agresif yang dibentuk oleh pola interaktif komunikasi dan kesempatan untuk menyalurkan perasaan agresivitas tersebut (Finkelhor, 1995). Penelitian ini akan menggunakan kerangka teoritis kognisi sosial yang dapat menjelaskan tentang bagaimana mekanisme pesan kekerasan fisik dan verbal yang diterima remaja direproduksi (Bandura, 2001). Tahapan kognisi sosial Bandura terjadi dalam empat tahap.

Pada tahap pertama seorang individu pembelajar "menghadiri" perilaku orang lain secara langsung atau tak langsung (dimediasi oleh sumber lainnya seperti televisi dan lainnya). Pada tahap kedua, individu pembelajar mengakui dan menyaring pengetahuan tentang perilaku tersebut. Tahap ketiga adalah tahap ketika individu pembelajar dapat mereproduksi apa yang dilihat dan didengarnya. Pada tahap keempat, individu pembelajar tersebut memilih untuk menerima perilaku tersebut untuk dijadikan pedoman perilaku. Keputusan untuk menerima perilaku tersebut ditentukan oleh konsekuensi yang mungkin diterima oleh individu pembelajar tadi (Kunkel et al., 2006).

Kendatipun telah banyak kajian tentang pengaruh pola asuh keluarga terhadap kekerasan remaja (Tis'Ina \& Suroso 2015; Yuniartiningtyas, 2013; Munawir, 2016), studi tentang kekerasan remaja pada sesama yang bersumber dari pola interaktif komunikasi keluarga belum banyak dilakukan. Penelitian tentang pengaruh komunikasi keluarga pada agresivitas remaja menjadi penting, karena keluarga adalah salah satu bagian dari interaksi komunikasi interpersonal remaja yang berperan membentuk "naskah kekerasan" (Ryan, 2005; Calvete \& Orue, 2012; Calvete \& Orue 2010). Pesan-pesan kekerasan yang bersumber dari interaksi interpersonal dalam konteks keluarga merupakan salah satu penyebab adanya naskah kekerasan pada remaja, yang dapat dipanggil ketika remaja membutuhkannya (Ryan, 2005). Beberapa laporan menyebutkan bahwa frekuensi kekerasan fisik, verbal, melihat penyerangan, dan jenis kekerasan lainnya biasanya dapat memprediksikan perilaku serupa di masa mendatang kepada sesama (Ryan, 2005). Kajian tentang pola komunikasi konflik dalam keluarga juga ditujukan untuk menghindari adanya "lingkaran setan," yaitu perulangan pesan kekerasan pada generasi selanjutnya karena sifat turun temurun keluarga (Klein \& White, 2002).

Pendekatan pola komunikasi konflik dalam lingkup keluarga dinilai penting untuk memahami kekerasan. Konflik orang tuaremaja terjadi karena orang tua merasa telah mengirimkan pesan-pesan verbal maupun nonverbal pada remaja, tetapi remaja tidak menangkap pesan tersebut (Klein \& White, 2002; García-Ruiz et al., 2013; Jutengren \& Palmerus, 2007). Pola komunikasi penting untuk dipelajari, karena pola menunjukkan urutan dan preseden dalam berkomunikasi antar anggota keluarga (Jenkins, 1995). Pola menyediakan kestabilan fungsi, keteraturan, dan kepercayaan diri. Cronen et al. (1981 diacu dalam Jenkins, 1995) menyatakan bahwa eksistensi peraturan bagi sistem sosial seperti keluarga ada untuk tiga alasan. Pertama, perilaku itu sesuatu yang terkadang dapat diprediksikan. Kedua, individu tergantung pada tanggung jawabnya. Ketiga, kebanyakan manusia berharap bahwa setiap manusia bertindak secara 'benar'. Hal inilah yang menimbulkan harapan-harapan dari anggota keluarga pada anggota lainnya. 
Permasalahan yang timbul adalah tidak semua keluarga menyosialisasikan harapan tersebut dalam komunikasi yang eksplisit. Selain itu, seringkali pesan tersebut lebih bersifat nonverbal sehingga memungkinkan adanya kesalahan penafsiran yang meningkat menjadi perilaku kekerasan. Kekerasan dalam keluarga berkaitan dengan keahlian berkomunikasi anggota keluarga. Ketidakefektifan komunikasi antar anggota keluarga seringkali mengakibatkan kekerasan (Anderson et al., 2004). Badan Pusat Statistik (BPS, 2013) mengungkapkan bahwa sekitar 3,07 persen perempuan dan anak mengalami tindak kekerasan dalam keluarga. Oleh karena itu, hipotesis utama yang akan diujikan pada penelitian ini adalah adanya pengaruh dari komunikasi keluarga pada kekerasan remaja pada sesama.

Salah satu dari pola komunikasi keluarga yang potensial menimbulkan konflik dan seringkali berujung pada kekerasan antar anggota keluarga adalah pola komunikasi saling menarik diri (Anderson et al., 2004). Seringkali orang tua dan remaja cenderung menghindari komunikasi konflik sehingga tidak terbentuk metakomunikasi yang memungkinkan adanya eksplorasi keinginan masing-masing pihak dalam berinteraksi (Caughlin \& Malis, 2004). Komunikasi orang tua-remaja yang cenderung menarik diri ditemukan berhubungan dengan penyesuaian yang buruk pada remaja, akan tetapi dampak komunikasi saling menarik diri terhadap frekuensi dan perasaan kekerasan remaja belum banyak ditemukan (Caughlin \& Malis, 2004).

Beberapa ahli menyarankan adanya pengawasan orang tua pada anak terutama yang menginjak usia remaja untuk mengatasi permasalahan kekerasan remaja (Crouter et al., 2005). Akan tetapi, beberapa pihak menganggap pengawasan justru akan memberikan keterbatasan pada anak (Stattin \& Kerr, 2000). Para ahli yang meragukan peran pengawasan mengajukan solusi untuk menjembatani cara mendapatkan pengetahuan tentang aktivitas remaja dengan kerelaan yang berasal dari diri remaja sendiri (Hamza \& Willoughby, 2011; Frijns et al., 2010). Solusi yang dapat dilakukan adalah dengan cara meningkatkan komunikasi antara orang tua dan remaja (Stattin \& Kerr, 2000; Van Ee, 2012). Komunikasi antara orang tuaremaja berisikan komponen "self disclosure" (keterbukaan remaja pada orang tua) dan "problem free communication" (kenyamanan berkomunikasi dengan orang tua) (Stattin \& Kerr, 2000; Barnes \& Olson, 1985).
Penelitian kekerasan remaja pada sesama yang mengambil peubah faktor komunikasi dalam keluarga dan karakteristik sosial ekonomi, dan gender dengan mengambil contoh remaja juga belum banyak dikaji. Laporan terdahulu menyebutkan bahwa karakteristik sosial ekonomi merupakan salah satu penduga kekerasan dalam keluarga dan agresivitas remaja pada sesama. Semakin bertambah usia anak maka semakin banyak anak terekspos oleh kekerasan (Puspitawati et al., 2011). Selanjutnya, berkaitan dengan gender, beberapa studi menemukan bahwa agresi fisik lebih banyak dialami oleh anak laki laki dibandingkan pada anak perempuan, sedangkan agresi verbal lebih banyak dialami oleh anak perempuan dibandingkan pada anak laki-laki (Galea, 2010; Idemudia \& Makhubela, 2011). Oleh karenanya, menjadi penting untuk melihat juga pengaruh karakteristik sosial ekonomi dan gender terhadap agresivitas remaja pada sesama.

Berdasarkan hal tersebut maka tujuan penelitian ini adalah: 1) menganalisisi pengaruh komunikasi keluarga terhadap agresivitas remaja pada sesama; 2) menganalisis pengaruh karakteristik sosial ekonomi dan gender terhadap komunikasi keluarga; dan 3) menganalisis pengaruh karakteristik sosial ekonomi dan gender terhadap agresivitas remaja pada sesama. Adapun hipotesis yang penelitian ini terdiri dari: 1) Hipotesis 1: komunikasi keluarga berpengaruh terhadap pada agresivitas remaja pada sesama; 2) Hipotesis 2: karakteristik sosial ekonomi dan gender berpengaruh terhadap komunikasi keluarga; dan 3) Hipotesis 3: karakteristik sosial ekonomi dan gender berpengaruh terhadap agresivitas remaja pada sesama.

\section{METODE}

Kajian ini menggunakan metode kuantitatif dengan desain cross sectional study. Pengumpulan data dilakukan dengan teknik survei dan laporan diri. Pengumpulan, pengolahan, dan analisis data dilakukan selama enam bulan (Januari-Juni 2016).

Populasi penelitian ini adalah siswa SMA/K di Kota dan Kabupaten Bogor. Bogor dipilih sebagai lokasi karena tingginya aksi tawuran dan kenakalan remaja lainnya (Puspitawati, 2008; Situmorang et al., 2016) sehingga dianggap dapat mewakili lokasi dengan tingkat kekerasan yang tinggi. Berdasarkan data yang didapatkan dari Dinas Pendidikan Kota dan Kabupaten Bogor, jumlah populasi siswa yang 
terdaftar sebanyak 18.928 siswa. Dari hasil penelusuran data sekunder dengan Dinas Pendidikan Kota dan Kabupaten Bogor didapatkan data tentang sekolah-sekolah yang memiliki tingkat kenakalan yang dianggap tinggi. Selanjutnya dilakukan pengacakan sederhana dengan teknik pengacakan berstrata. Teknik pengacakan berstrata (stratified random sampling) adalah cara mengambil contoh dengan memperhatikan strata (tingkatan) di dalam populasi (Sugiyono, 2008).

Ada tujuh SMA/K yang terpilih sebagai sekolah contoh (empat sekolah berada di Kota dan tiga sekolah berada di wilayah Kabupaten Bogor). Total contoh remaja yang diperoleh berdasarkan Rumus Slovin (galat kesalahan lima persen) adalah 367 remaja. Sebanyak 227 orang contoh adalah remaja laki-laki sedangkan contoh remaja perempuan berjumlah 140 orang. Responden di setiap sekolah ditentukan sebanyak 1-2 kelas. Responden diberitahukan dan dimintakan izin tertulis untuk berpartisipasi dalam penelitian ini. Pada pelaksanaannya, responden diperlakukan secara anonim dan tidak boleh untuk menuliskan nama pada bagian manapun dari kuesioner. Penerapan azas anonimitas dan rahasia ini, penting untuk membuat kenyamanan responden dalam menjawab instrumen-instrumen yang sensitif karena terkait dengan perlakuan yang pernah diterima tentang kekerasan dari orang tuanya sendiri. Kuesioner disampaikan dengan metode seperti ujian (exam-like) dan diselesaikan dalam waktu antara 30-90 menit.

Responden harus memenuhi kriteria remaja tengah menjelang akhir, yaitu dalam kisaran usia 14-17 tahun pada saat pengambilan data (bulan Januari-Maret 2016). Fokus pada kelompok umur ini diperlukan karena remaja pada usia ini ditemukan sedang berada pada masa negosiasi ulang hubungan dengan orang tua (Feldman, 2011). Negosiasi ulang dibutuhkan untuk memenuhi tuntutan tugas utama remaja yaitu menghadapi tahapan idetitas melawan peran kekacauan (identity versus identity confusion) (Santhrock, 2007), sehingga pada masa ini banyak terjadi konflik antara orang tua dan remaja.

Penelitian ini mengambil data primer yang terdiri atas (1) Karakteristik sosial ekonomi dan gender, (2) komunikasi saling menarik diri orang tua-remaja, (3) perilaku komunikasi kekerasan verbal dan fisik orang tua, (4) komunikasi orang tua-remaja, (5) agresi remaja pada sesama.
Komunikasi saling menarik diri orang tuaremaja menggunakan Communication Pattern Questionnaire (Heavey et al., 1996; Crenshaw et al., 2016). Instrumen ini mengukur komunikasi saling menarik diri orang tuaremaja. Pertanyaan seperti: ketika ada konflik, kedua belah pihak saling menghindar dan tidak mau mendiskusikan masalah bersangkutan. Respon dikategorikan menjadi 1 (sangat tidak mungkin terjadi) hingga 7 (sangat mungkin terjadi). Reliabilitas komunikasi saling menarik diri ayah-remaja dan komunikasi saling menarik diri ibu-remaja adalah 0,624.

Perilaku komunikasi kekerasan verbal dan fisik orang tua menggunakan Conflict Tactics Scale (CTS) Children Version yang telah dimodifikasi. Contoh pernyataannya, "ayah/ibu menghina saya, ayah/ibu menakut-nakuti saya, dan lainnya". Responnya adalah tidak pernah, sekali, dua kali, 3-5 kali, 6-10 kali, 11-20 kali dan lebih dari 20 kali. Respon tersebut kemudian dikode $0,1,2,4,8,15$ dan 25. Hasil uji relibialitas menunjukkan nilai Cronbach $\alpha$ kekerasan verbal ayah adalah 0,870, kekerasan verbal ibu adalah 0,861 , kekerasan fisik ayah adalah 0,886 , kekerasan fisik ibu adalah 0,891 . Komunikasi orang tua-remaja menggunakan Parent-Adolescent Communication yang dikembangkan oleh Barnes \& Olson (1985). Contoh pernyataannya adalah "saya dapat mengatakan pendapat saya tanpa merasa terbebani atau malu, orang tua saya adalah pendengar yang baik, dan lainnya". Respon dibagi menjadi lima yaitu sangat setuju, setuju, ragu ragu, tidak setuju, dan sangat tidak setuju. Nilai Cronbach's $\alpha$ komunikasi ayah-remaja adalah 0,742 dan komunikasi ibu-remaja adalah 0,694.

Agresivitas remaja pada sesama diukur dengan menggunakan The Aggression Scale dan The Agression Questionnaire (Buss \& Perry, 1992). The Aggression Scale terdiri atas 11 butir pernyataan yang dirancang untuk mengukur perilaku agresif/kekerasan (selfreported) remaja, dengan mengukur perilaku yang mungkin secara psikologis maupun fisik membahayakan orang lain. Skala ini dapat memberikan informasi tentang frekuensi dari perilaku agresif/kekerasan termasuk kekerasan verbal (menghina, pemanggilan dengan sebutan buruk, menganjurkan remaja lain untuk berkelahi, mengancam untuk menyakiti atau memukul), dan kekerasan fisik (mendorong, menampar, menendang, memukul), juga informasi mengenai amarah remaja (mudah marah, marah sepanjang hari). Untuk meminimalkan bias yang mungkin terjadi, skala ini menggali informasi tentang 
perilaku dalam kurun tujuh hari ke belakang (Orpinas \& Frankowski, 2001). Respon dikategorikan dari 0 hingga 6 atau lebih $(\alpha=0,834)$.

The Agression Questionnaire yang memiliki empat faktor, yaitu agresi fisik, contohnya adalah "sesekali, saya tidak dapat menahan diri untuk menyerang orang lain". Faktor kedua, agresi verbal, contoh pertanyaannya adalah "saya sering menemukan kalau saya tidak sependapat dengan pendapat orang lain". Faktor ketiga, kemarahan contohnya, "kadang-kadang, saya merasa seperti bahan eksplosif yang siap meledak". Faktor keempat, kekejaman contohnya, "kadang-kadang, perasaan saya dipenuhi oleh iri hati". Instrumen ini memiliki nilai Cronbach's alpha yang memadai $(\alpha=0,854)$.

Analisis yang digunakan adalah: (1) analisis deskriptif; (2) analisis independent sample $t$ test untuk menilai perbedaan faktor-faktor komunikasi dan agresi remaja berdasarkan jenis kelamin (laki-laki dan perempuan). Independent sample t-test juga digunakan untuk menilai perbedaan faktor-faktor komunikasi dan agresi remaja berdasarkan lokasi (kabupaten-kota); dan (3) analisis persamaan struktural (Structural Equation Modelling) dengan Lisrel 8.8.

\section{HASIL}

\section{Karakteristik Sosial Ekonomi Demografi Remaja}

Berdasarkan hasil analisis, diketahui bahwa jumlah remaja laki-laki contoh di kota lebih banyak (64,8 persen) dibandingkan dengan remaja perempuan (26,1 persen), sebaliknya remaja laki-laki contoh di kabupaten lebih sedikit (35,2 persen) daripada remaja perempuan (72,9 persen). Rata-rata umur remaja pada penelitian ini adalah 16,5 tahun. Seluruh responden dalam penelitian ini adalah keluarga yang masih tinggal dengan ayah dan ibunya serta memiliki keluarga utuh. Pendidikan ayah terendah adalah tamat Sekolah Dasar (SD), dan paling tinggi S3 dengan rata-rata lulus Sekolah Menegah Pertama (SMP). Pendidikan ibu terendah adalah kelas 4 Sekolah Dasar (SD), dan paling tinggi Magister (S2), dengan rata-rata tingkat pendidikan adalah lulus Sekolah Menegah Pertama (SMP). Rata-rata umur ayah adalah 46,62 tahun, sedangkan umur ibu 42,0 tahun. Sementara itu, rata-rata jumlah anak adalah 4 orang per keluarga.
Tabel 1 Statistik deskriptif peubah karakteristik sosial ekonomi

\begin{tabular}{lrrrr}
\hline $\begin{array}{c}\text { Peubah } \\
\text { karakteristik sosial } \\
\text { ekonomi }\end{array}$ & Min Maks & $\begin{array}{c}\text { Rata- } \\
\text { rata }\end{array}$ & $\begin{array}{c}\text { Simpangan } \\
\text { Baku }\end{array}$ \\
\hline Umur remaja & 1 & 21 & 16,55 & 1,44 \\
Jumlah saudara & 1 & 11 & 3,24 & 1,58 \\
Umur ayah & 36 & 75 & 46,62 & 7,12 \\
Umur ibu & 30 & 65 & 42,07 & 6,45 \\
Pendidikan ayah & 6 & 21 & 9,63 & 3,48 \\
Pendidikan lbu & 4 & 18 & 8,92 & 3,14 \\
Pendapatan total & 0 & 12 & 3,01 & 2,19 \\
\hline
\end{tabular}

Berkaitan dengan kondisi ekonomi keluarga, pendapatan keluarga berkisar dari $\mathrm{Rp} 0,00$ hingga Rp12.000.000,00 per bulan, dengan rata-rata pendapatan keluarga adalah Rp3.600.000,00.

Perbedaan rata-rata remaja laki-laki dan perempuan. Hasil analisis uji beda pada Tabel 2 menemukan adanya perbedaan signifikan antara remaja laki-laki dan perempuan pada peubah kekerasan verbal ibu pada remaja $(p=0,050)$, kekerasan fisik ayah pada remaja $(p=0,016)$, dan komunikasi saling menarik diri ayah-remaja $(p=0,002)$. Hasil menunjukkan bahwa remaja laki-laki (rata-rata $=6,93$ ) mendapatkan kekerasan fisik dari ayah lebih sering dibandingkan dengan remaja perempuan (rata-rata $=3,43$ ). Selain itu, remaja laki-laki (rata-rata $=3,830$ ) juga memiliki pola komunikasi saling menarik diri dengan ayah lebih besar dari pada remaja perempuan (ratarata $=3,153$ ). Sementara itu, remaja perempuan (rata-rata $=30,85$ ) lebih sering mendapatkan kekerasan verbal dari ibu dibandingkan remaja laki-laki (rata-rata=21,17).

Berdasarkan hasil uji beda $t$, perbedaan signifikan juga ditemukan antara remaja lakilaki dan perempuan pada peubah frekuensi kekerasan remaja pada sesama $(p=0,010)$ dan agresi fisik remaja pada sesama $(p=0,000)$. Temuan tersebut menunjukkan bahwa remaja laki-laki lebih sering berkeinginan atau melakukan kekerasan pada sesama, juga lebih sering menerima agresi fisik pada sesama dibandingkan dengan remaja perempuan (Tabel 2).

Perbedaan rata-rata berdasarkan tempat tinggal. Penelitian ini juga menemukan bahwa peubah yang memiliki signifikansi berbeda antara kota dan kabupaten adalah frekuensi agresi remaja pada sesama $(p=0,009)$. Artinya, bahwa frekuensi agresi remaja di kota lebih tinggi dibandingkan dengan frekuensi agresi remaja di kabupaten. 
Tabel 2 Statistik deskriptif dan koefisien uji beda t komunikasi orang tua-remaja menurut jenis kelamin remaja

\begin{tabular}{|c|c|c|c|c|}
\hline Peubah komunikasi keluarga & $\begin{array}{c}\text { Jenis } \\
\text { kelamin }\end{array}$ & Rata-rata $\pm S D$ & $\mathrm{t}$ & p-value \\
\hline \multirow[t]{2}{*}{ Kekerasan fisik ayah } & Laki-laki & $6,93 \pm 22,55$ & 1,707 & \multirow{2}{*}{$0,050^{* *}$} \\
\hline & Perempuan & $3,43 \pm 11,47$ & 1,965 & \\
\hline \multirow[t]{2}{*}{ Kekerasan verbal Ibu } & Laki-laki & $21,17 \pm 32,88$ & $-2,430$ & \multirow{2}{*}{$0,016^{* *}$} \\
\hline & Perempuan & $30,85 \pm 42,98$ & $-2,284$ & \\
\hline \multirow{2}{*}{$\begin{array}{l}\text { Komunikasi saling menarik diri ayah- } \\
\text { remaja }\end{array}$} & Laki-laki & $3,830 \pm 21,97$ & 2,977 & \multirow{2}{*}{$0,002^{*}$} \\
\hline & Perempuan & $3,153 \pm 19,78$ & 3,052 & \\
\hline \multirow[t]{2}{*}{ Frekuensi agresi remaja pada sesama } & Laki-laki & $2,292 \pm 202,48$ & 3,41 & \multirow{2}{*}{$0,001^{*}$} \\
\hline & Perempuan & $1,621 \pm 145,29$ & 3,68 & \\
\hline \multirow[t]{2}{*}{ Agresi Fisik remaja pada sesama } & Laki-laki & $4,013 \pm 16,09$ & 4,86 & \multirow{2}{*}{$0,000^{*}$} \\
\hline & Perempuan & $3,195 \pm 14,89$ & 4,95 & \\
\hline
\end{tabular}

\section{Pengaruh faktor komunikasi pada frekuensi dan perasaan agresivitas remaja terhadap sesama}

Berdasarkan hasil analisisanalisis SEM, didapatkan hasil karakteristik sosial ekonomi yang terdiri atas jenis kelamin, tempat tinggal, dan pendapatan keluarga memiliki pengaruh pada komunikasi keluarga dan kekerasan remaja pada sesama. Komunikasi keluarga yang terdiri atas komunikasi ayah-remaja, komunikasi ibu-remaja, kekerasan verbal dan fisik ayah, kekerasan verbal dan fisik ibu, komunikasi saling menarik diri ayah-remaja, dan komunikasi saling menarik diri ibu-remaja berpengaruh pada kekerasan remaja pada sesama. Kekerasan remaja pada sesama terdiri atas frekuensi agresi, agresi fisik, agresi verbal, kemarahan, dan kekejaman. Berdasarkan tabel GOF (Tabel 3), sebagian besar indikator menunjukkan bahwa model SEM sudah fit atau sudah baik. Sebagian besar indikator menunjukkan bahwa model SEM sudah fit sehingga layak untuk digunakan. Hasil analisis SEM, seperti the
Normed Fit Index (NFI), Comparative Fit Index (CFI), atau Root Mean Squared Error of Approximation (RMSEA) ditemukan good fit (Tabel 3).

\section{Uji Hipotesis}

Hipotesis 1, komunikasi keluarga memiliki pengaruh signifikan dan negatif pada agresivitas remaja pada sesama, dengan nilai $t$ hitung 5,58 (t hitung > t tabel alpha 5\%) artinya hipotesis diterima. Hal ini menunjukkan bahwa semakin rendah komunikasi keluarga semakin tinggi agresivitas remaja pada sesama.

Hipotesis 2, karakteristik sosial ekonomi dan gender berpengaruh signifikan dan positif pada komunikasi keluarga, dengan nilai $t$ hitung 4,44 (t hitung > t tabel alpha 5,0 persen 1,96 artinya hipotesis diterima. Hal ini menunjukkan bahwa ada pengaruh karakteristik sosial ekonomi dan gender seperti jenis kelamin, tempat tinggal (kabupaten-kota), dan pendapatan keluarga terhadap komunikasi keluarga.

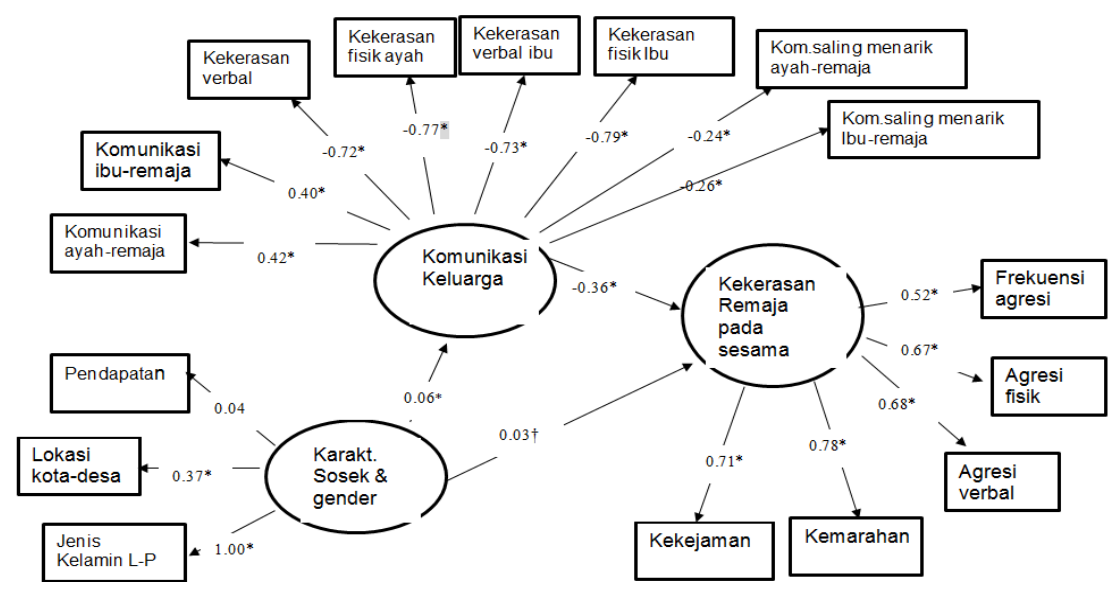

Chi-square $=245,02, \mathrm{df}=82, \mathrm{P}$-value $=0,00000, \mathrm{RMSEA}=0,074$

Gambar 1 Model standardized loading factor Karakteristik sosial ekonomi dan gender, komunikasi keluarga terhadap kekerasan remaja pada sesama 
Tabel 3 Hasil kriteria kesesuaian model SEM

\begin{tabular}{lrrr}
\hline \multicolumn{1}{c}{ Goodness-of-Fit } & Cutt-off-Value & Hasil & Keterangan \\
\hline RMR(Root Mean Square Residual) & $\leq 0,05$ atau $\leq 0,1$ & 0,07 & Good Fit \\
RMSEA(Root Mean square Error of Approximation) & $\leq 0,08$ & 0,074 & Good Fit \\
GFI(Goodness of Fit) & $\geq 0,90$ & 0,96 & Good Fit \\
AGFI(Adjusted Goodness of Fit Index) & $\geq 0,90$ & 0,94 & Good Fit \\
CFI (Comparative Fit Index) & $\geq 0,90$ & 0,94 & Good Fit \\
Normed Fit Index (NFI) & $\geq 0,90$ & 0,91 & Good Fit \\
Non-Normed Fit Index (NNFI) & $\geq 0,90$ & 0,94 & Good Fit \\
Incremental Fit Index (IFI) & $\geq 0,90$ & 0,94 & Good Fit \\
Relative Fit Index (RFI) & $\geq 0,90$ & 0,94 & Good Fit \\
\hline
\end{tabular}

Hipotesis 3, karakteristik sosial ekonomi dan gender berpengaruh signifikan dan positif pada agresivitas remaja pada sesama dengan nilai $t$ hitung 1.65 (t hitung $>\mathrm{t}$ tabel alpha 10,0 persen 1,645) artinya hipotesis diterima. Hal ini menunjukkan bahwa ada pengaruh karakteristik sosial ekonomi dan gender seperti jenis kelamin, tempat tinggal (kabupaten-kota), dan pendapatan keluarga terhadap komunikasi keluarga.

\section{PEMBAHASAN}

Secara umum, temuan dalam studi ini menguatkan teori kognisi sosial. Pembahasan mengenai bagaimana remaja mendapatkan skema kekerasan dari lingkungan keluarga yang merupakan lingkungan utama dan pertama pada proses sosialisasi (Janicik, 2014; Ardebili \& Golshani, 2016; Calvete \& Orue, 2012) juga dilaporkan sebagai hasil penelitian ini.

\section{Pengaruh Komunikasi Keluarga terhadap Agresivitas Remaja}

Hipotesis pertama dalam penelitian ini adalah komunikasi keluarga berpengaruh siginifikan dan negatif terhadap agresivitas remaja pada sesama. Temuan penelitian menunjukkan bahwa penurunan komunikasi keluarga berpengaruh terhadap peningkatan kekerasan remaja pada sesama. Temuan ini menguatkan teori Bandura (2001), tentang reproduksi pesan kekerasan yang menyatakan bahwa perilaku kekerasan dipelajari dari lingkungannya melalui proses peniruan. Remaja adalah individu pembelajar yang mampu menyerap agresivitas lingkungan keluarganya untuk direproduksi menjadi perilaku yang sama di masa mendatang. Penelitian ini juga menguatkan temuan Ryan (2005) dan Finkelhor (1995) yang menyatakan bahwa seseorang perlu memiliki kapasitas abusive untuk melakukan kekerasan pada sesama melalui pengamatan dari lingkungan sosialnya dan akan digunakan pada situasi sosial yang mirip.
Kajian ini menemukan bahwa peningkatan perilaku kasar orang tua secara fisik dan verbal menyebabkan peningkatan proses komunikasi menarik diri antara ayah dan remaja. Peningkatan perilaku kasar orang tua secara fisik dan verbal juga memengaruhi peningkatan frekuensi agresi remaja pada sesama baik dalam bentuk agresi fisik dan verbal, kemarahan, dan kekejaman remaja pada sesama. Penelitian ini menguatkan penelitian sebelumnya yang menyatakan bahwa semakin seseorang menarik diri dengan pasangan komunikasinya maka berpotensi menimbulkan hasil-hasil remaja menjadi semakin jelek (Caughlin \& Malis, 2004; Luk et al., 2010; Moylan et al., 2011). Temuan ini juga menguatkan temuan sebelumnya yang dilakukan oleh Weiss \& Dehle (2013) yang menyatakan bahwa komunikasi yang cenderung menarik diri antarpasangan bukan merupakan komunikasi sehat karena sifatnya yang menyembunyikan konflik. Konflik yang disembunyikan cenderung menjadi besar dan menjadi potensi kekerasan (latent), dan suatu saat bisa muncul di masa depan.

\section{Pengaruh Karakteristik Sosial Ekonomi dan Gender terhadap Komunikasi Keluarga}

Penelitian ini menemukan bahwa karakteristik sosial ekonomi dan gender berpengaruh pada komunikasi keluarga. Karakteristik keluarga seperti pendapatan keluarga dan gender dapat memprediksikan proses-proses komunikasi keluarga. Keluarga dari kelas sosial yang lebih rendah seringkali kesulitan memenuhi kebutuhan-kebutuhannya yang seringkali menimbulkan stres dalam pengasuhan dan proses komunikasi sehingga seringkali ditemukan lebih kasar pada anak-anak (Fatima \& Sheikh, 2014).

Usia dan Gender. Penelitian ini menemukan bahwa usia anak yang semakin muda menyebabkan penurunan komunikasi ayahremaja. Komunikasi ayah-remaja pada studi ini, menggunakan konsep self disclosure dan 
problem free communication. Temuan ini menguatkan penelitian terdahulu, yang menyatakan bahwa anak-anak melakukan self disclosure lebih kepada ibu dibandingkan pada ayah sehingga ayah lebih sedikit mengetahui aktifitas keseharian anak (Hosley \& Montemayor, 1997).

Beberapa penelitian terdahulu menyatakan bahwa ayah sedikit terlibat dan kurang dapat terhubung dalam melakukan percakapan, sebagai akibatnya hubungan antara ayah dan remaja menjadi cuek, lemah, dan berjarak dibandingkan dengan hubungan antara remaja dengan ibu (Hosley \& Montemayor, 1997; Lamb \& Lewis, 2010). Keterlibatan ayah juga semakin berkurang ketika remaja dengan menarik diri dalam proses komunikasi yang dilakukan dengan anak remajanya (pada kisaran usia 13-15), yang biasanya diikuti juga oleh penarikan diri ayah di level yang sama (Lamb \& Lewis, 2010).

Ayah, pada penelitian ini, ditemukan lebih sering melakukan kekerasan fisik kepada remaja laki-laki dibandingkan pada remaja perempuan. Temuan ini sejalan dengan penelitian Guterman \& Lee (2005). Beberapa penelitian tentang kekasaran komunikasi menyatakakan bahwa jika anak dikasari, baik secara verbal maupun fisik, akan terbentuk jarak yang memungkinkan orang tua dipandang sebagai figur yang "jauh" (Rohner \& Rohner, 1980). Oleh karenanya, tidak mengherankan jika penelitian ini menemukan bahwa ayah dan remaja laki-laki ditemukan lebih menarik diri dari proses komunikasi. Selain hal-hal di atas, penyebab kurang terbukanya remaja laki-laki pada ayah juga akibat sosialisasi pada remaja laki-laki untuk membatasi ekspresi emosionalnya dari remaja awal hingga remaja akhir. Sementara itu, remaja perempuan memiliki kebebasan untuk melakukannya, yang merupakan bagian dari "peraturan" bahwa "anak laki-laki akan berkurang kejantanannya jika memperlihatkan emosi seperti menangis, dan lainnya" (McNaughton, 2000; Helgeson, 2012).

Hasil penelitian menemukan bahwa ibu lebih sering melakukan kekerasan verbal kepada remaja perempuan dibandingkan pada remaja laki-laki, yang sejalan dengan penelitian (Guterman \& Lee, 2005). Salah satu teori yang dapat menjelaskan adalah karena sejak kecil perempuan lebih banyak disosialisasikan aktivitas yang mengasah kemampuan verbal (Helgeson, 2012). Kajian terdahulu juga menyatakan bahwa remaja perempuan lebih sering terbuka pada ibunya dibandingkan dengan remaja laki-laki. Jika dikelola dengan baik, keterbukaan antara ibu-remaja perempuan dapat menumbuhkan perasaan empati (Heller et al., 2008), tetapi jika ibu dan remaja kurang dapat mengelolanya maka biasanya akan meningkat menjadi kekerasan verbal.

\section{Pengaruh Karakteristik Sosial Ekonomi dan Gender terhadap Agresivitas Remaja}

Temuan lain dalam penelitian ini adalah karakteristik sosial ekonomi dan gender berpengaruh terhadap agresivitas remaja pada sesama. Artinya adalah ada pengaruh karakteristik sosial ekonomi (berupa pendapatan keluarga), gender, dan tempat tinggal (kabupaten-kota) terhadap agresivitas remaja pada sesama.

Pendapatan keluarga. Hasil analisis SEM menunjukkan adanya pengaruh pendapatan keluarga pada agresivitas remaja. Temuan ini konsisten dengan penelitian tentang kemiskinan sebagai salah satu faktor yang hampir selalu konsisten berkaitan dengan agresivitas remaja. Remaja yang berasal dari tingkat ekonomi rendah berpeluang dua hingga tiga kali memiliki masalah kesehatan mental dan agresi dibandingkan dengan keluarga kaya (Tremblay, 1999). Agresivitas juga lebih tinggi peluangnya pada keluarga yang tinggal di lingkungan keluarga miskin (Singh \& Gandour, 2012). Singkatnya, kemiskinan dan ketiadaan sumber daya hampir selalu ditemukan berhubungan dengan agresi (Fatima \& Sheikh, 2014).

Tempat tinggal. Hasil uji beda menunjukkan bahwa terdapat perbedaan remaja perkotaan dan pedesaan pada frekuensi agresi dan agresi fisik. Kendatipun penelitian ini tidak meneliti tentang stres remaja kabupaten-kota, menurut beberapa ahli, stres remaja perkotaan lebih tinggi sehingga memungkinkan remaja perkotaan memiliki agresivitas lebih tinggi (Smokowski et al., 2012).

Usia dan Gender. Penelitian ini menguatkan temuan sebelumnya tentang paparan kekerasan di usia remaja (Puspitawati, 2008). Temuan ini juga menguatkan beberapa temuan sebelumnya tentang gender. Beberapa studi menyatakan bahwa kekerasan fisik lebih banyak dialami oleh anak laki laki dibandingkan pada anak perempuan, sedangkan agresi tidak langsung lebih banyak dialami oleh anak perempuan (Galea, 2010; Idemudia \& Makhubela, 2011; Tsorbatzoudis et al., 2013; Calvete \& Orue, 2013). 
Remaja laki-laki pada studi ini, ditemukan lebih sering melakukan perilaku agresi dan lebih agresif secara fisik dibandingkan remaja perempuan. Temuan ini menguatkan penelitian terdahulu yang dilakukan oleh Moretti et al. (2012) dan Lansford et al. (2012). Sementara itu, pada agresi verbal, kemarahan, dan kekejaman tidak ditemukan berbeda. Penelitian ini menguatkan penelitian sebelumnya tentang kekerasan dan agresi fisik yang memang lebih banyak dilakukan oleh anak dan remaja laki-laki dibandingkan dengan perempuan (Odgers \& Moretti 2002; Swaim et al., 2006). Studi ini tidak konsisten dengan temuan Smokowski et al. (2012) yang menyatakan bahwa remaja perempuan lebih agresif dibandingkan remaja laki-laki. Gender merupakan salah satu faktor yang konsisten dapat memprediksikan agresi (Anderson \& Bushman, 2002). Secara umum laki-laki terlibat lebih banyak perilaku agresif baik secara fisik maupun verbal, akan tetapi beberapa penelitian menyebutkan bahwa remaja perempuan lebih biasa melakukan agresi tak langsung atau relasional (Helgeson, 2012; Estévez et al., 2012). Penelitian terdahulu menyebutkan bahwa anak laki-laki diharapkan memiliki fokus pada kekuasaan dan hierarki (Tannen, 1990). Anak laki-laki juga diharapkan lebih waspada, lebih kuat, lebih terkoordinasi, sementara anak perempuan diharapkan lebih lembut dan rapuh (Berns, 2004). Perilaku kasar orang tua pada anak laki-laki dianggap sebagai salah satu cara untuk memperoleh tujuan-tujuan tersebut (McNaughton, 2000). Namun, hal tersebut membutuhkan penelitian lanjutan karena penelitian ini tidak secara langsung meneliti tentang sosialisasi nilai pada remaja laki-laki dan perempuan.

\section{SIMPULAN DAN SARAN}

Kajian ini menguatkan teori kognisi sosial Bandura tentang reproduksi pesan kekerasan. Penelitian ini dapat dijelaskan bagaimana pesan kekerasan direproduksi melalui interaksi dengan lingkungan keluarga pada proses komunikasi keluarga. Faktor-faktor yang secara laten merupakan peubah komunikasi adalah komunikasi ayah-remaja, komunikasi ibu-remaja, kekerasan fisik ayah dan ibu pada remaja, kekerasan verbal ayah dan ibu pada remaja, dan komunikasi saling menarik diri ayah dan ibu dengan remaja; berpengaruh terhadap agresivitas remaja pada sesama. Karakteristik sosial ekonomi, gender dan tempat tinggal juga memiliki pengaruh signifikan terhadap komunikasi keluarga dan kekerasan remaja pada sesama.
Kajian ini memiliki implikasi tentang penguatan komunikasi positif dalam keluarga untuk menghindari adanya perulangan pesan kekerasan dari satu generasi ke generasi selanjutnya. Kajian ini juga dapat digunakan oleh pihak pengambil kebijakan terkait untuk melakukan langkah-langkah strategis penguatan komunikasi di dalam lingkup keluarga untuk mencegah agresi remaja pada sesama.

\section{DAFTAR PUSTAKA}

Allen, J. J., \& Anderson, C. A. (2015). Aggression and violence: Definition and distinction. Dalam P. Sturmey (Ed.), The Wiley Handbook of Violence and Aggression. Hoboken NJ: Wiley.

Anderson, C.A. \& Bushman, B. J.( 2002). Human aggression. Annual Review of Psychology, 53, 27-51.

Anderson, K. L,, Umberson, D., \& Elliot, S. (2004). Violence and Abuse in Families. Dalam A. L. Vangelisti (Ed.), Handbook of Family Communication (pp. 629-645). London, UK: LEA.

Ardebili, E.F. \& Golshani, F. (2016). Early maladaptive schemas and aggression based on the birth order of children. Modern Applied Science, 10(9), 14-21. doi:10.5539/mas.v10n9p14.

[BPS]. Badan Pusat Statistik. (2013). Violence against women survey in Indonesia. The 2006 national socio economic survey (SUSENAS) prosiding workshop on improving the integration of gender perspective into official status. Chiba, Japan, 16-19 April 2013.

Bandura, A. (2001). Social cognitive theory of mass communication. Mediapsychology 3, 265-299.

Barnes, H. L., \& Olson, D. H. (1985). Parentadolescent communication and the circumplex model. Child development, 56, 435-447.

Berns, R. (2004). Child, family, school, community: socialization and support (6th ed.). Belmont, CA: Thomson Learning.

Buss, A.H. \& Perry, M. (1992). The aggression questionnaire. Journal Personal Social Psychology, 63, 452-459.

Calvete, E. \& Orue, I. (2010. Cognitive schemas and aggressive behavior in adolescents: The mediating role of social information processing. The Spanish 
Journal of Psycholog, 13 (1), 190-201. doi: https://doi.org/10.1017/S113874160 0003772.

Calvete, E. \& Orue, I. (2012). Social information processing as a mediator between cognitive schemas and aggressive behavior in adolescents. Journal of Abnormal Child Psychology, 40 (1), 105-117. doi:10.1007/s10802011-9546-y.

Calvete, E. \& Orue, I. (2013). Cognitive mechanisms of the transmission of violence: Exploring gender differences among adolescents exposed to family violence. Journal of Family Violence, 28 (1), 73-84. doi:10.1007/s10896-0129472-y.

Caughlin, J. P. \& Malis, R. S. (2004). Demand/ withdraw communication between parents and adolescents: Connections with self-esteem and substance use. Journal of Social and Personal Relationships, 21(1), 125-148.

Crenshaw, A. O., Christensen, A. , Baucom, D. H., Epstein, N. B., \& Baucom, B. R. (2016). Revised scoring and improved reliability for the communication patterns questionnaire. Psychological Assessment. doi: 10.1037/pas0000385.

Crouter, A. C., Bumpus, M. F., Davis, K. D., \& McHale, S. M. (2005). How do parents learn about adolescents' experiences? Implications for parental knowledge and adolescent risky behavior. Child Development,76, 869-882.

Estévez, E., Povedano, A., Jiménez, T. I., \& Musitu, G. (2012). Aggression in adolescence. In Guevara, B. C., \& Becerra, N. A. (Eds.), Psychology of Aggression: New Research, pp. 37-57. Nova Science Publishers.

Fatima, S. \& Sheikh, H. (2014). Socioeconomic status and adolescent aggression: The role of executive functioning as a mediator. The American Journal of Psychology, 127 (4), 419-430.

Feldman, R.S. (2011). Understanding of psychology. Tenth edition. New York: McGrawHill.

Finkelhor, D. (1995). The victimization of children: A developmental perspective. American Journal of Orthopsychiatry, 65(2), 177-193.

Frijns, T., Keijsers, L., Branje, S., \& Meeus, W. (2010). What parents don't know and how it may affect their children: Qualifying the disclosure-adjustment link. Journal of Adolescence, 33, 261270.

Galea, M. (2010). Does child maltreatment mediate family environment and psychological well-being? Psychology, 1, 143-150. doi:10.4236/psych.2010.12019.

García-Ruiz, M., Rodrigo, M.J., HernándezCabrera, J.A. Máiquez, M. L., \& Deković, M. (2013). Resolution of parent-child conflicts in the adolescence. European Journal of Psychology Education, 28(2), 173-188.

Guterman, N. B. \& Lee, Y. (2005). The role of fathers in risk for physical child abuse and neglect: Possible pathways and unanswered questions. Child Maltreatment, 10, 136-149.

Hamza, C.A. \& Willoughby, T. J. (2011). Perceived parental monitoring, adolescent disclosure, and adolescent depressive symptoms: A longitudinal examination. Youth Adolescence, 40(7), 902-915.

Heavey, C. L., Larson, B. M., Zumtobel, D. C., \& Christensen, A. (1996). The communication patterns questionnaire: The reliability and validity of a constructive communication subscale. Journal of Marriage and Family, 58(3), 796-800.

Heller, S. R., Robinsoon, L. C., Henry, C. S., \& Plunkett, S. W. (2008). Gender differences in adolescent perceptions of parent-adolescent openness in communication and adolescent empathy. Journal Marriage \& Family Review, 40(4), 103-122. http://dx.doi.org/10.1300/J002v40n04_06

Helgeson, V. S., (2012) The psychology of gender. 4th ed. New Jersey, US: Pearson Education

Hosley, C. A., \& Montemayor, R. (1997). Fathers and adolescents. In M. E. Lamb (Ed.), The role of the father in child development (3rd ed.) (pp. 162-178). Hoboken, NJ US: John Wiley Sons Inc.

Idemudia, E. \& Makhubela. (2011). Gender difference, exposure to domestic violence and adolescents' identity development. Gender \& Behaviour, 9(1). $3443-3465$.

Janicik, J. (2014). Gender schemas, parenting styles, and aggression. Verbum, 12(1). 
Diambil

dari http://fisherpub.sjfc.edu/verbum/vol12/iss 1/2 [diunduh 22 Nov 2016].

Jenkins, K. (1995). Communication in families. In R. D. Day, K.R. Gilbert, B.H. Settles, \& W.R. Burr (Eds.), Research and Theory in Family Science. Brooks/Cole Publishing Company ITP.

Jutengren, G. \& Palmerus. (2007). The Potential Role of Conflict resolution Schemas in Adolescent Psychosocial Adjustment . Social Indicators Research, 83 (1), 25-38.

Klein, J. M. \& White, D. M. (2002). Family theories an introduction. London: Sage Publication.

Kunkel, A., Hummert, M.L, \& Dennis, M. R. (2006). Social learning theory: modelling and communication in family context. In Braithwaite, D.O., Baxter, L. A. Engaging theories in family communication multiple perspectives. Londong: Sage Publication.

Lamb, M. E. \& Lewis, C. (2010). The development and significance of fatherchild relationships in two-parent families. In M. E. Lamb (Ed.), The role of the father in child development (5th ed.) (pp. 94-153). Hoboken, NJ US: John Wiley \& Sons Inc.

Lansford, J.E., Skinner, A. T., Sorbring, E., Giunta, L. D., Deater-Deckard, K., Dodge, K. A., Malone, P. S., Oburu, P. , Pastorelli, C., Tapanya, S., Tirado, L. M. U., Zelli, C.A., Al-Hassan, S.M., Alampay, J.L.P., Bacchini, P.D., Bombi, A.S., \& Bornstein, M.H., (2012). Boys' and girls' relational and physical aggression in nine countries. Aggression Behavior, 38(4), 298-308.

Lochman, J. E. \& Dodge, K. A. (1998). Distorted perceptions in dyadic interactions of aggressive and nonaggressive boys: Effects of prior expectations, context, and boys' age. Development and psychopathology, 10, 495-512.

Luk, J. W., Farhat, T., lannotti, R. J., \& Simons-Morton, B. G., (2010). Parentchild communication and substance use among adolescents: Do father and mother communication play a different role for sons and daughters? Addictive Behaviors, 35, 426-431.

McNaughton, J., \& Niedzwiecki, C. K. (2000). Gender differences in parent child communication pattern. Communication Studies and Women's Studies, 25-32. Diambil dari http://www.uwlax.edu. [diunduh 26 Des 2016].

Moretti, M.M., Rosalind, E.H., Catchpole, M.A., \& Odgers, C. (2012). The Dark Side of Girlhood: Recent Trends, Risk Factors and Trajectories to Aggression and Violence. Aggressive Behavior, 38(4), 298-308. doi:10.1002/ab.21433.

Moylan, C. A., Herrenkohl, T. I., Sousa, C., \& Tajima, E.A., Herrenkohl, R.C., \& Russo, M. J., (2011). The Effects of Child Abuse and Exposure to Domestic Violence on Adolescent Internalizing and Externalizing Behavior Problems. Journal of Family Violence, 25(1), 53-63. doi:10.1007/s10896-009-9269-9

Munawir, M. (2016). Dampak perbedaan pola asuh terhadap perilaku agresif remaja di SMA 5. Prosiding Seminar Asean 2nd, Psychology \& Humanity, UMM 19 - 20 Februari 2016.

Odgers, C. L. \& Moretti, M. M. (2002). Aggressive and antisocial girls: research update and challenge. International Journal of Forensic Mental Health, 1, 103-119.

Orpinas, P. \& Frankowski, R., (2001). The aggression scale: A self-report measure of aggressive behavior for young adolescents. Journal of Early Adolescence, 21(1), 50-67.

Puspitawati, H., Djamaludin, D., \& Nursanti, H. (2011). Kekerasan, kondisi keluarga dan kesejahteraan keluarga pada anak korban kekerasan. Jurnal IImu Konsumen dan Keluarga, 4(2), 130-138.

Puspitawati, H. (2008). Pengaruh komunikasi keluarga, lingkungan teman dan sekolah terhadap kenakalan pelajar pada sekolah menengah di Kota Bogor. Jurnal IImiah Pekerjaan Sosial, 7(2), 287-306.

Rina. (2011). Faktor- faktor yang melatarbelakangi perilaku agresif pada remaja. Jurnal Kesehatan Prima. 3 (2). $1-11$.

Rohner, R. P. \& Rohner, E. C. (1980). Antecedents and consequences of parental rejection: A theory of emotional abuse. Child Abuse and Neglect, 4, 189198.

Ryan, G. (2005). Preventing violence and trauma in the next generation. Journal of 
Interpersonal Violence, 20(1), 132-141. doi: $10.1177 / 0886260504268605$

Santhrock, J. W. (2007). Remaja Edisi 11 Jilid 1. Jakarta: Penerbit Erlangga.

Setyawan, D. (2014). Tawuran pelajar memprihatinkan dunia pendidikan. Diambil dari http://www.kpai.go.id/artikel/tawuranpelajar-memprihatinkan-duniapendidikan/. [diunduh 14 Mei 2016].

Singh, G.K. \& Ghandour, R.M. (2012). Impact of neighborhood social conditions and household socioeconomic status on behavioral problems among US children. Maternal and Child Health Journal, 16(1), 158-S169.

Situmorang, Z., R., Hastuti, D., \& Herawati, T. (2016). The influence of comunication and attachment with peers on adolescence character in rural area. Journal of Child Development Studies, 1(2), 34-44.

Smokowski, P. R., Cotter, K. L., Robertson, C. I. B., \& Guo, S. (2012). Anxiety and aggression in rural youth: Baseline results from the rural adaptation project. Child Psychiatry of Human Development. doi 10.1007/s10578-012-0342-x.

Stattin, H. \& Kerr, M. (2000). Parental monitoring: A reinterpretation. Child Development, 71(4), 1072-1085.

Sugiyono. (2008). Metode Penelitian Kuantitatif, Kualitatif dan $R \& D$. Bandung : Penerbit Alfabeta.

Swaim, R. C., Henry, K. L., \& Kelly, K. (2006). Predictors of aggressive behaviors among rural middle school youth. Journal of Primary Prevention, 27(3), 229-244.

Tannen, D. (1990). You just don't understand: Women and men in conversation. New York: Ballantine Books.
Tis'Ina, N. A. \& Suroso. (2015) Pola asuh otoriter, konformitas dan perilaku school bullying. Persona Jurnal Psikologi Indonesia, 4(2), 153-161.

Tremblay, R.E. (1999). When children's social development fails. In: Keating, D.P., Hertzman, C. (Eds.), Developmental Health and the Wealth of Nations: Social, Biological, and Educational Dynamics. Guildford Press, New York, pp. 55-71.

Tsorbatzoudis, H., Travlos, A. K., \& Rodafinos, A. (2013). Gender and age differences in self-reported aggression of high school students. Journal Interpers Violence, 28(8), 1709-1725.

Van Ee, E., Koetzier, L., Voerman, K., \& Skyler, T. (2012). Parental monitoring strategies and middle adolescents' information sharing on social networking sites (Disertasi). Pedagogical Sciences University Utrecht.

Verona, E. \& Kilmer, A. (2007). Stress exposure and affective modulation of aggressive behavior in men and women. Journal of Abnormal Psychology, 116(2), 410-421.

Verona, E., Sadeh, N., Case, S. M., Reed II, E. \& Bhattacharjee, E. (2008). Self-reported use of different forms of aggression in late adolescence and emerging adulthood. Assessment, 15(4). 493-510.

Weiss, R. L. \& Dehle, C. (2013). Perspectives on marital conflict. Dalam D. D. Cahn (Ed.), Conflict in Personal Relationship. New York: Routledge Taylor and Francis Group.

Yuniartiningtyas, F. (2013). Hubungan antara pola asuh orang tua dan tipe kepribadian dengan perilaku bullying di sekolah pada siswa SMP (Skripsi). Universitas Negeri Malang, Malang, Indonesia. 